\title{
Influence of Aveiro Lagoon heavy metal contents in the adjacent continental shelf (Portugal)
}

\section{Influencia de la Laguna de Aveiro en los contenidos de metales pesados en la plataforma continental adyacente (Portugal)}

\author{
I. Abrantes ${ }^{1}$ \\ F. Rocha ${ }^{2 *}$ \\ J. Vidinha ${ }^{2}$ \\ J.A. Dias ${ }^{3}$ \\ ${ }^{1}$ E.S.E./Instituto Superior Politécnico de Viseu \\ R. Dr Maximiano Aragão \\ 3500 Viseu, Portugal \\ ${ }^{2}$ Centro de Minerais Industriais e Argilas \\ Universidade do Aveiro \\ Campus de Santiago \\ 3810 Aveiro, Portugal \\ *E-mail: frocha@geo.ua.pt \\ ${ }^{3}$ Universidade do Algarve \\ UCTRA, Campus de Gambelas \\ 8000 Faro, Portugal
}

Recibido en junio de 2003; aceptado en mayo de 2004

\begin{abstract}
A chemical analysis of $\mathrm{Al}, \mathrm{Ca}, \mathrm{Fe}, \mathrm{Mg}, \mathrm{Cu}, \mathrm{Pb}, \mathrm{Zn}, \mathrm{Cr}, \mathrm{Co}, \mathrm{Ni}$ and $\mathrm{Cd}$ was carried out in 22 surface sediment samples of the continental shelf and upper slope between Espinho and Aveiro (Portugal). To reduce the disturbing effects of grain size, all samples were size-normalized by wet sieving $(<63 \mu \mathrm{m})$. The fine fraction was digested with concentrated acids and analyzed by flame atomic absorption spectrometry. The Al and heavy metal concentrations displayed a similar distribution pattern, decreasing seaward. Exceptions to this general pattern are $\mathrm{Ca}, \mathrm{Mg}$ and $\mathrm{Pb}$ distributions. The Ca contents are related to carbonated biogenic particles that are very abundant in the outer shelf. Multivariate statistical analysis was applied to all data to assess the behaviour and sources of each element analyzed. The results from factor analysis showed that terrigenous supply (from Aveiro Lagoon flow, coastal erosion and littoral drift), grain size (clay) sorting and anthropogenic influences from Aveiro Lagoon are the major factors controlling spatial variations of chemical elements in the continental shelf between Espinho and Aveiro. Unusually high contents of $\mathrm{Pb}$ were found in the middle shelf off Furadouro, but we could not determine the possible source of this contamination.
\end{abstract}

Key words: heavy metals, sediments, continental shelf, Aveiro Lagoon, multivariate statistical analysis.

\section{Resumen}

Se realizaron análisis químicos de Al, Ca, Fe, Mg, Pb, Zn, Cr, Co, Ni y Cd en 22 muestras de sedimento superficial de la plataforma y vertiente continental entre Espinho y Aveiro (Portugal). Para reducir el efecto de la granulometría del sedimento, se normalizó el tamaño de las muestras mediante tamizado $(<63 \mu \mathrm{m})$. Se procedió a la digestión de la fracción fina con ácidos concentrados y se analizó mediante espectrometría de absorción atómica con llama. Las concentraciones de Al y metales pesados muestran un patrón de distribución similar, disminuyendo hacia la vertiente. Las excepciones a este patrón general son las distribuciones de $\mathrm{Ca}, \mathrm{Mg}$ y $\mathrm{Pb}$. El contenido de Ca está relacionado con las partículas biogénicas carbonatadas que son muy abundantes en la plataforma externa. Con el objetivo de determinar el comportamiento y el origen de cada uno de los elementos analizados, se aplicaron técnicas de análisis estadístico multivariante. Los resultados obtenidos muestran que los principales factores que controlan las variaciones espaciales de los elementos químicos en la plataforma continental entre Espinho y Aveiro son los sedimentos terrígenos procedentes de la Laguna de Aveiro, de la erosión costera y de la deriva litoral; el tamaño de grano (tamaño arcillas); y la influencia antropogénica en la Laguna de Aveiro. En la plataforma media, a la altura de Furadouro, se encontraron valores elevados de $\mathrm{Pb}$, aunque no hemos podido determinar la posible fuente de esta contaminación.

Palabras clave: metales pesados, sedimentos, plataforma continental, Laguna de Aveiro, análisis estadístico multivariante. 


\section{Introduction}

Several studies regarding mineralogical distribution in the fine fractions of the sediments from the Portuguese Atlantic coast and continental platform in relation to circulation/ paleocirculation have been carried out during the last decade (Drago et al., 2002; Machado et al., 1999a, 1999b, 2000, 2001a, 2001b, 2002; Martins et al., 2001a, 2001b, 2002; Oliveira et al., 1998, 2000, 2001, 2002; Vidinha et al., 1998, $2000,2002)$. The main topics were and still are:

1. Analyses of the mineralogical and chemical composition of littoral beach and dune sands aiming to determine the source rocks of sediments, their pathways into the presentday deposits, the reworking processes, the determination of shoreline stability and the dispersion of pollution.

2. Investigations of the mineralogical composition of seabottom sediments, of suspended particulate materials and on cores, together with paleontological and geochemical data, aiming at paleoclimatic and paleoenvironmental reconstructions, sea-level changes analysis, identification of stratigraphic correlations, past and present sources of the sediments and means of terrigenous supply, dispersion of pollution and, finally, to describe the present oceanic water masses.

The northern Portuguese shelf is characterized by a highly energetic hydrodynamic regime of waves and tides. In the summer, northerly winds drive a coastal upwelling (Wooster et al., 1976; Fiúza et al., 1982; Fiúza, 1983), with an associated equatorward flow on the shelf, whereas during the winter, westerly winds with a southerly component promote downwelling with poleward flow (Drago et al., 1998; Vitorino et al., 2000, 2002).

The surface sediments of this sector of the Portuguese continental shelf came, essentially, from the Douro watershed, located at the northern extremity of this coastal sector, and also from the Vouga watershed, that drains to a wide lagoon (Aveiro Lagoon), which in turn is connected to the Atlantic Ocean through an artificial inlet. Mainly granites, schists and greywackes outcrop in the Douro watershed, while gneisses, migmatites, granitoids, micaschists, schists, sandstones and shales outcrop in the Vouga watershed and in the surrounding region of Aveiro Lagoon.

Geological studies of the sediments of the continental shelf and upper slope between Espinho and Aveiro have been carried out (Abrantes, 1994; Abrantes and Magalhães, 2000; Abrantes et al., 1994, 2001, 2002; Cascalho, 2000; Cascalho and Magalhães, 2000) using sedimentological, paleoecological, geochemical and mineralogical analysis of sediment samples collected systematically in this sector of the Portuguese Atlantic coast. The surface sediments of the continental shelf and upper slope between Espinho and Aveiro have been characterizeded by the authors, based on both sediment

\section{Introducción}

En la última década se han realizado varios trabajos sobre la distribución mineralógica en las fracciones finas de sedimentos de la costa Atlántica y plataforma continental de Portugal en relación con la circulación y paleocirculación (Drago et al., 2002; Machado et al., 1999a, 1999b, 2000, 2001a, 2001b, 2002; Martins et al., 2001a, 2001b, 2002; Oliveira et al., 1998, 2000, 2001, 2002; Vidinha et al., 1998, 2000, 2002). Los temas principales han sido y siguen siendo:

1. El análisis de la composición mineralógica y química de la arena de playas y dunas costeras para determinar las fuentes rocosas de sedimentos, sus rutas a los depósitos actuales, los procesos de retrabajamiento, la determinación de la estabilidad costera y la dispersión de la contaminación.

2. Estudios sobre la composición mineralógica de sedimentos del fondo del mar, de material particulado en suspensión y en núcleos, junto con datos paleontológicos y geoquímicos, para llevar a cabo reconstrucciones paleoclimáticas y paleoambientales, así como análisis de cambios en el nivel del mar, identificar las correlaciones estratigráficas, las fuentes de sedimentos en el pasado y actuales y de contribución terrígena, la dispersión de la contaminación y, finalmente, describir las masas de agua oceánica actuales.

La plataforma del norte de Portugal se caracteriza por un régimen hidrodinámico altamente energético de olas y mareas. En el verano, los vientos del norte generan surgencias costeras (Wooster et al., 1976; Fiúza et al., 1982; Fiúza, 1983) con un flujo ecuatorial asociado sobre la plataforma, mientras que en el invierno los vientos del oeste con un componente meridional producen hundimiento convectivo con flujo hacia el polo (Drago et al., 1998; Vitorino et al., 2000, 2002).

Los sedimentos superficiales de esta zona de la plataforma continental portuguesa provienen, esencialmente, de la cuenca hidrográfica del Douro, localizada en el extremo norte de esta zona costera, así como de la cuenca hidrográfica del Vouga, que se vierte en una laguna amplia, la Laguna de Aveiro. Esta laguna a su vez se conecta con el Océano Atlántico mediante una ensenada artificial. En la cuenca del Douro afloran principalmente granitos, esquistos y grauvacas, mientras que en la del Vouga y en la región adyacente a la Laguna de Aveiro afloran gneises, migmatitas, granitoideos, micacitas, esquistos, areniscas y pizarras.

Se han llevado a cabo estudios geológicos de los sedimentos de la plataforma y vertiente continental entre Espinho y Aveiro (Abrantes, 1994; Abrantes y Magalhães, 2000; Abrantes et al., 1994, 2001, 2002; Cascalho, 2000; Cascalho y Magalhães, 2000) mediante análisis sedimentológicos, paleoecológicos, geoquímicos y mineralógicos de muestras de sedimento recolectadas sistemáticamente en esta zona de la costa Atlántica portuguesa. Los autores han caracterizado los sedimentos superficiales de la plataforma y vertiente 
texture and coarse-fraction granulometric and compositional analysis.

The study area is located in the western Portuguese continental margin, between $40^{\circ} 31^{\prime} \mathrm{N}$ and $40^{\circ} 58^{\prime} \mathrm{N}$ (fig. 1). The shelf is narrow, ranging from $38 \mathrm{~km}$, near Aveiro Canyon, to 50 km, off Furadouro.

Mesozoic carbonate rocks outcrop at the middle and outer shelf. The bottom sedimentary cover is dominated by sand particles, in the inner shelf ( $>30 \mathrm{~m}$ ) by fine sand, in the mid-shelf (30-80 m) by coarse sand and gravel, and in the outer shelf by carbonate-rich sand, poorly sorted. Gravel particles occur essentially along two bands correlated with paleo-littorals. The fine fraction content is generally low (average 5\%), increasing from the coast to the upper slope (fig. 1). The fine fraction content is probably related to the effectiveness of Aveiro Lagoon as a natural sediment trap, the sedimentary dynamics of this region and the bathymetric control.

This shallow coastal lagoon (also known as Ría de Aveiro) separated from the sea by a sand bar discharges into the shelf through an artificial channel. The flows from the Vouga and Antuã rivers are the most important input of fresh water into this lagoon. During a tidal cycle the total mean river discharge is about $1.8 \times 10^{6} \mathrm{~m}^{3}$ (Moreira et al., 1993), although the tidal prism at the mouth during a spring tide, with a tidal range of $2.48 \mathrm{~m}$, is about $70 \times 10^{6} \mathrm{~m}^{3}$ (Vicente, 1985). At low tide, water covers an area of $66 \mathrm{~km}^{2}$, while at high tide, this area increases to $83 \mathrm{~km}^{2}$ (Dias et al., 1999). The lagoon provides conditions for harbour, navigation and naval industry and is still a place of industrial and domestic waste discharges.

Waters flowing from the north, mainly from the Douro River, extend their influence to the study area through littoral drift currents. The continental area drained to this shelf is almost dominated by granitic and schist-graywake formations.

Though the sedimentology and mineralogy of the shelf sediments of this region are well known (Dias and Nittrouer, 1984; Dias, 1987; Magalhães, 1993, 1999; Abrantes, 1994; Abrantes et al., 1994, 2001; Abrantes and Magalhães, 2000; continental entre Espinho y Aveiro con base tanto en la textura del sedimento como en el análisis granulométrico y composicional de la fracción gruesa.

El área de estudio se localiza en el margen continental occidental portugués, entre $40^{\circ} 31^{\prime} \mathrm{N}$ y $40^{\circ} 58^{\prime} \mathrm{N}$ (fig. 1). La plataforma es angosta, desde 38 km cerca del cañón de Aveiro hasta $50 \mathrm{~km}$ enfrente de Furadouro.

En la plataforma media y externa afloran rocas carbonatadas mesozoicas. La cobertura sedimentaria del fondo está dominada por partículas de arena, la de la plataforma interna (>30 m) por arena fina, la de la plataforma media (30-80 m) por arena gruesa y grava, y la de la plataforma externa por arena rica en carbonatos, pobremente distribuida. Las partículas de grava se presentan principalmente a lo largo de dos bandas correlacionadas con paleolitorales. El contenido de la fracción fina es generalmente bajo (promedio 5\%), incrementándose de la costa a la vertiente (fig. 1), y probablemente esté relacionado con la eficacia de la Laguna de Aveiro como trampa natural de sedimento, con la dinámica sedimentaria de la región y con el control batimétrico.

Esta laguna costera somera (también conocida como Ría de Aveiro), separada del mar por una barra de arena, se vierte hacia la plataforma por medio de un canal artificial. Los flujos de los ríos Vouga y Antuã son los principales contribuyentes de agua dulce a la laguna. Durante un ciclo de marea, la descarga total media de río es alrededor de $1.8 \times 10^{6} \mathrm{~m}^{3}$ (Moreira et al., 1993), aunque el prisma de marea en la boca durante las mareas vivas, con un intervalo de marea de $2.48 \mathrm{~m}$, es alrededor de $70 \times 10^{6} \mathrm{~m}^{3}$ (Vicente, 1985). Durante la bajamar, el agua cubre un área de $66 \mathrm{~km}^{2}$, mientras que durante la marea alta, ésta llega a cubrir un área de $83 \mathrm{~km}^{2}$ (Dias et al., 1999). La laguna proporciona condiciones para un puerto, navegación e industria naval, e incluso recibe descargas industriales y domésticas.

Las aguas provenientes del norte, principalmente del Río Douro, extienden su influencia sobre el área de estudio mediante corrientes costeras. El área continental que drena

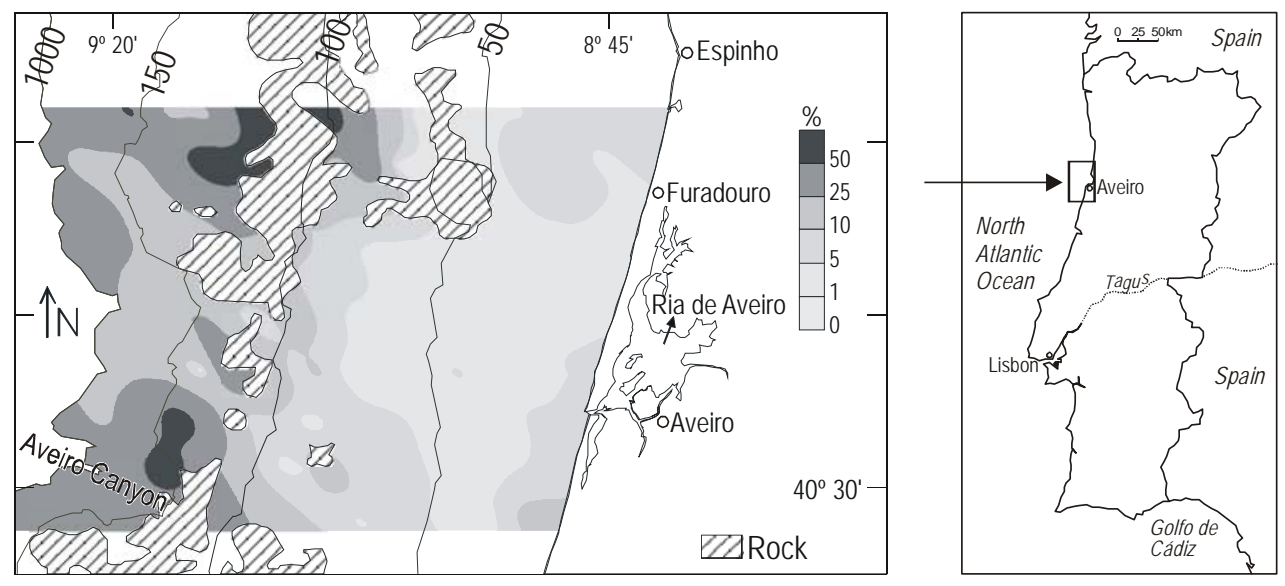

Figure 1. Geographic setting of the study area and distribution of the fine fraction.

Figura 1. Localización geográfica del área de estudio y distribución de la fracción fina. 
Cascalho, 2000; Cascalho and Magalhães, 2000), there is a lack of information on the geochemistry of the surface sediments.

This work aims to evaluate the distribution of several elements, in particular the heavy metals, in the fine fraction of the surface sediments and to correlate trace metal content with natural or anthropogenic inputs.

\section{Materials and methods}

The 22 shelf sediment samples analyzed were collected using a Smith-McIntyre grab, during several cruises conducted under the SEPLAT program, promoted by the Portuguese Hydrographic Institute, between 1988 and 1990 (fig. 2).

To reduce the effects of variable grain size on the chemical and mineralogical composition, only the fine fraction $(<63 \mu \mathrm{m})$ was analyzed. This fraction was obtained by wet sieving and dried at $60^{\circ} \mathrm{C}$. Chemical analysis to determine $\mathrm{Al}, \mathrm{Ca}, \mathrm{Fe}, \mathrm{Mg}$, $\mathrm{Cu}, \mathrm{Pb}, \mathrm{Zn}, \mathrm{Cr}, \mathrm{Co}, \mathrm{Ni}$ and $\mathrm{Cd}$ was carried out by flame atomic absorption spectrometry on a GBC 600 spectrophotometer.

The chemical analysis of the sediment samples was carried out following the method proposed by Lecomte and Sondag (1980): $1 \mathrm{~g}$ of sediment was digested with a mixture of $3 \mathrm{~mL}$ of $\mathrm{HCl}(37 \%), 2 \mathrm{~mL}$ of $\mathrm{HNO}_{3}$ (65\%) and $1 \mathrm{~mL}$ of $\mathrm{HF}(40 \%)$. After drying at $120^{\circ} \mathrm{C}$, the residue was mixed with $10 \mathrm{~mL}$ of $\mathrm{HNO}_{3}$. The resultant solution was centrifuged, filtered and mixed with demineralized water.

The quality of the analysis was tested by simultaneously extracting and analyzing duplicate samples. To control the analytical process and check for possible batch errors, samples from one batch were included in other batches. The precision of the analytical results was estimated by replicate analysis (Garrett, 1973). Analytical precision, defined as the percent relative standard variation at the $95 \%$ confidence level, ranged from $4 \%$ to $12 \%$ for the elements analyzed, considering the $\mathrm{P}_{0.05}$ significance level.

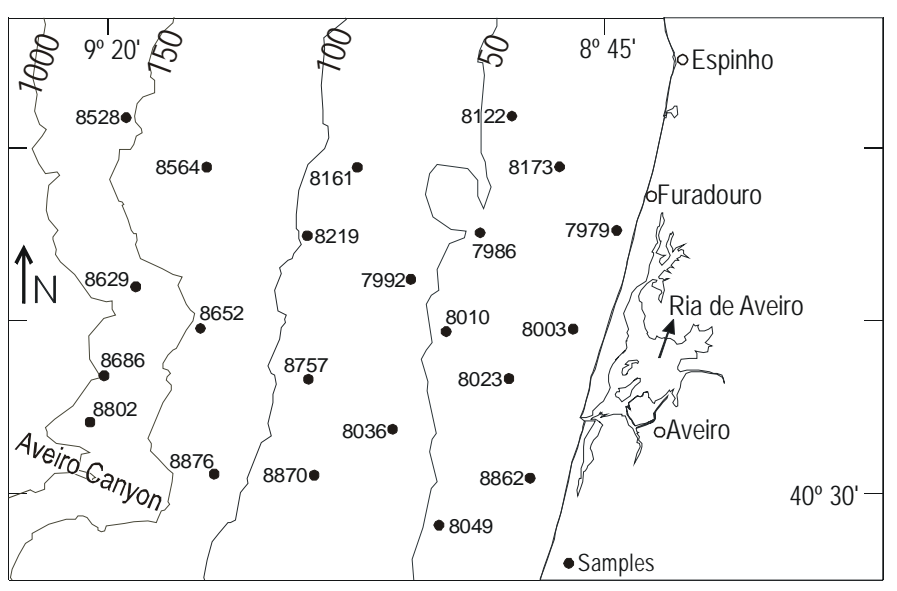

Figure 2. Sampling stations. Figura 2. Estaciones de muestreo. hacia esta plataforma está casi totalmente dominada por formaciones graníticas y de grauvacas y esquistos.

A pesar de que se conoce bien la sedimentología y mineralogía de los sedimentos de la plataforma de esta región (Dias y Nittrouer, 1984; Dias, 1987; Magalhães, 1993, 1999; Abrantes, 1994; Abrantes et al., 1994, 2001; Abrantes y Magalhães, 2000; Cascalho, 2000; Cascalho y Magalhães, 2000), falta información sobre la geoquímica de los sedimentos superficiales.

Los principales objetivos del presente trabajo fueron evaluar la distribución de varios elementos, en particular los metales pesados, en la fracción fina de los sedimentos superficiales, y correlacionar el contenido de metales traza con aportes naturales o antropogénicos.

\section{Materiales y métodos}

Las 22 muestras de sedimento de la plataforma analizadas fueron recolectadas mediante una draga tipo Smith-McIntyre, durante varios cruceros realizados como parte del programa SEPLAT, del Instituto Hidrográfico Portugués, entre 1988 y 1990 (fig. 2).

Para reducir los efectos del tamaño de grano variable sobre la composición química y mineralógica, se analizó sólo la fracción fina $(<63 \mu \mathrm{m})$. Esta fracción se obtuvo mediante tamizado húmedo y se secó a $60^{\circ} \mathrm{C}$. Se llevó a cabo un análisis químico para determinar $\mathrm{Al}, \mathrm{Ca}, \mathrm{Fe}, \mathrm{Mg}, \mathrm{Cu}, \mathrm{Pb}, \mathrm{Zn}, \mathrm{Cr}, \mathrm{Co}$, Ni y Cd por medio de espectrometría de absorción atómica con llama, utilizando un espectrómetro GBC 600.

El análisis químico de las muestras de sedimento fue realizado según el método propuesto por Lecomte y Sondag (1980): se digirió $1 \mathrm{~g}$ de sedimento con una mezcla de $3 \mathrm{~mL}$ de $\mathrm{HCl}$ (37\%), $2 \mathrm{~mL}$ de $\mathrm{HNO}_{3}$ (65\%) y $1 \mathrm{~mL}$ de $\mathrm{HF}$ (40\%). Después de secar a $120^{\circ} \mathrm{C}$, se mezcló el residuo con $10 \mathrm{~mL}$ de $\mathrm{HNO}_{3}$. La solución obtenida se centrifugó, filtró y mezcló con agua desmineralizada.

La calidad del análisis fue comprobada mediante la extracción y análisis simultáneo de muestras por duplicado. Para controlar el proceso analítico y detectar posibles errores, las muestras de un lote fueron incluidas en otros lotes. La precisión de los resultados analíticos fue estimada por análisis de réplicas (Garrett, 1973). La precisión analítica, definida como el porcentaje de variación estándar relativa al nivel de confianza de $95 \%$, varió de $4 \%$ a $12 \%$ para los elementos analizados, considerando un nivel de significancia de $\mathrm{P}_{0.05}$.

Los datos obtenidos fueron sometidos a un análisis estadístico multivariante (análisis de componentes principales), utilizando la paquetería Statistica (v. 5.0).

Se llevó a cabo el análisis multivariante (análisis de componentes principales) de los datos químicos para obtener una caracterización adecuada de los datos, mediante la reducción de la complejidad del modelo y la clasificación de las variables y muestras en grupos naturales, de acuerdo con Imbrie y Van Andel (1964), Jöreskob et al. (1976), Davis (1986), Mezzadri y Saccani (1989) y Reyment y Jöreskob (1993). 
The data obtained were submitted to multivariate statistical analysis (principal components analysis) using Statistica (v. 5.0) software.

Multivariate data analysis (principal components analysis) of the chemical data was carried out to obtain a convenient characterization of the data, through the reduction of the complexity of the model and classification of the variables and samples into natural groups, according to Imbrie and Van Andel (1964), Jöreskob et al. (1976), Davis (1986), Mezzadri and Saccani (1989) and Reyment and Jöreskob (1993).

\section{Results and discussion}

To compare sedimentary metal concentrations, a granulometric normalization approach was used to compensate grain size effects, according to Loring (1991). The concentrations of the elements analyzed in the fine fraction of the surface sediments studied are listed in table 1. Figures 3 and 4 show the distribution maps of these elements.

\section{Resultados y discusión}

Para comparar las concentraciones de metales en los sedimentos, se normalizó el tamaño de las muestras para reducir el efecto del tamaño de grano, según Loring (1991). En la tabla 1 se presentan las concentraciones de los elementos analizados en la fracción fina de los sedimentos superficiales estudiados. Las figuras 3 y 4 muestran los mapas de distribución de estos elementos.

Los valores de $\mathrm{Al}, \mathrm{Fe}$ y $\mathrm{Cu}$ se encuentran dentro de los niveles de base aceptados hoy en día (Salomons y Föstener, 1984), mientras que $\mathrm{Pb}, \mathrm{Zn}$, Cr y Ni muestran algunos valores anómalos, mayores que los niveles de base actualmente aceptados, los cuales pueden estar relacionados con la contaminación antropogénica. Todas las muestras tienen concentraciones de Cd menores que el límite de detección ( $\left.0.05 \mathrm{mg} \mathrm{kg}^{-1}\right)$.

Las mayores concentraciones de $\mathrm{Al}$ fueron encontradas a profundidades por encima de $100 \mathrm{~m}$. Por el contrario, los contenidos de Ca se incrementaron hacia el oeste, con valores más

Table 1. Elemental concentrations in the fine fraction $(<63 \mu \mathrm{m})$ of the surface sediments (values in $\mathrm{mg} \mathrm{kg}^{-1} \mathrm{unless}$ otherwise indicated).

Tabla 1. Concentración de los elementos en la fracción fina $(<63 \mu \mathrm{m})$ de los sedimentos superficiales (valores en mg $\mathrm{kg}^{-1}$ a menos que se indique lo contrario).

\begin{tabular}{ccrrrrrrrrrr}
\hline Samples & $\mathrm{Al}(\%)$ & $\mathrm{Ca}(\%)$ & $\mathrm{Fe}(\%)$ & $\mathrm{Mg}(\%)$ & $\mathrm{Cu}$ & $\mathrm{Pb}$ & $\mathrm{Zn}$ & $\mathrm{Cr}$ & $\mathrm{Co}$ & $\mathrm{Ni}$ \\
\hline 7979 & 8.1 & 2.4 & 3.3 & 1.2 & 22 & 59 & 134 & 179 & 41 & 128 \\
7986 & 5.1 & 9.5 & 2.3 & 1.1 & 17 & 91 & 94 & 65 & 36 & 73 \\
7992 & 7.5 & 6.2 & 3.7 & 1.3 & 25 & 127 & 135 & 83 & 39 & 83 \\
8003 & 9.0 & 2.4 & 3.2 & 1.1 & 20 & 51 & 136 & 190 & 39 & 129 \\
8010 & 8.5 & 5.7 & 3.4 & 1.3 & 28 & 110 & 160 & 78 & 47 & 87 \\
8023 & 9.4 & 5.3 & 3.3 & 1.3 & 29 & 93 & 175 & 82 & 36 & 76 \\
8049 & 7.8 & 7.6 & 3.5 & 17.7 & 24 & 116 & 140 & 88 & 42 & 91 \\
8036 & 8.8 & 7.1 & 3.8 & 1.2 & 26 & 100 & 145 & 75 & 37 & 73 \\
8122 & 6.9 & 5.4 & 2.4 & 0.9 & 15 & 89 & 92 & 76 & 39 & 71 \\
8161 & 6.8 & 6.2 & 3.3 & 1.0 & 22 & 63 & 112 & 63 & 36 & 64 \\
8173 & 5.5 & 5.1 & 1.7 & 1.1 & 13 & 235 & 71 & 92 & 39 & 86 \\
8219 & 4.9 & 9.6 & 2.7 & 1.0 & 21 & 74 & 99 & 94 & 32 & 93 \\
8528 & 2.6 & 18.2 & 2.6 & 0.8 & 17 & 68 & 80 & 57 & 24 & 67 \\
8564 & 6.7 & 7.9 & 3.6 & 1.1 & 26 & 56 & 111 & 68 & 38 & 87 \\
8629 & 4.4 & 10.8 & 1.9 & 1.2 & 18 & 51 & 74 & 72 & 29 & 78 \\
8652 & 6.2 & 10.2 & 2.6 & 1.4 & 21 & 62 & 96 & 62 & 33 & 75 \\
8686 & 5.4 & 12.8 & 2.6 & 1.2 & 19 & 52 & 92 & 62 & 31 & 70 \\
8757 & 9.9 & 8.9 & 3.6 & 20.6 & 23 & 74 & 130 & 104 & 36 & 92 \\
8802 & 4.6 & 12.3 & 2.2 & 1.0 & 20 & 48 & 83 & 47 & 25 & 71 \\
8862 & 8.2 & 4.0 & 3.2 & 1.2 & 23 & 73 & 122 & 90 & 38 & 86 \\
8870 & 8.2 & 9.2 & 3.8 & 1.3 & 25 & 83 & 135 & 78 & 37 & 91 \\
8876 & 2.0 & 20.1 & 4.3 & 1.3 & 14 & 60 & 83 & 83 & 24 & 66 \\
\hline
\end{tabular}


Al

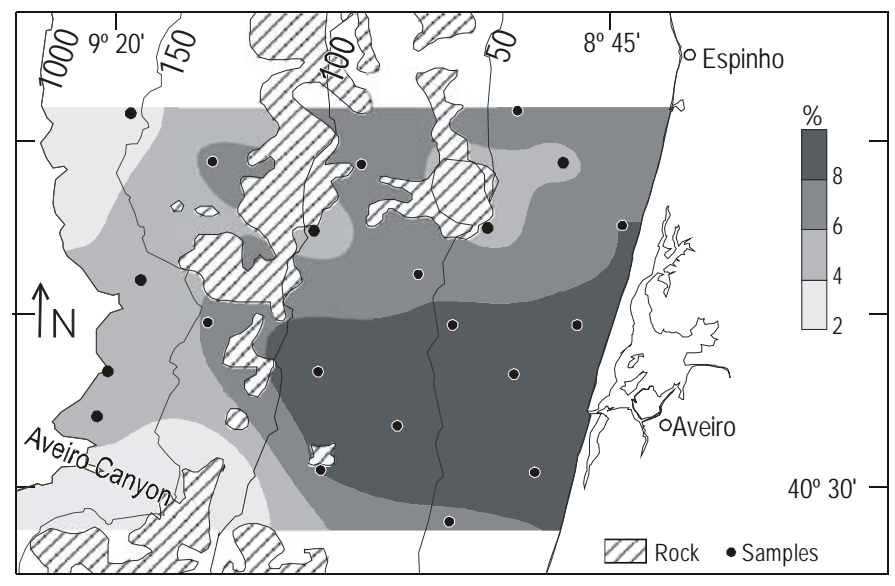

$\mathrm{Fe}$

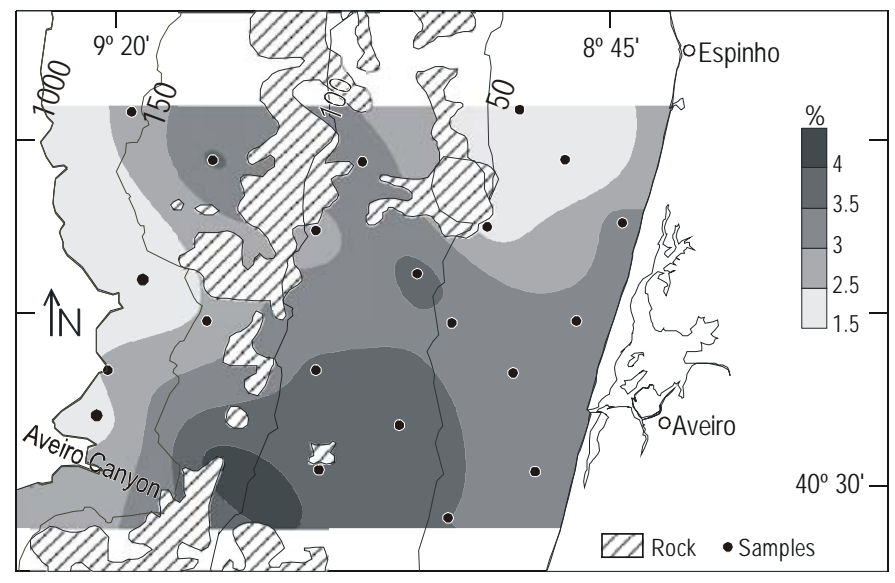

$\mathrm{Cu}$

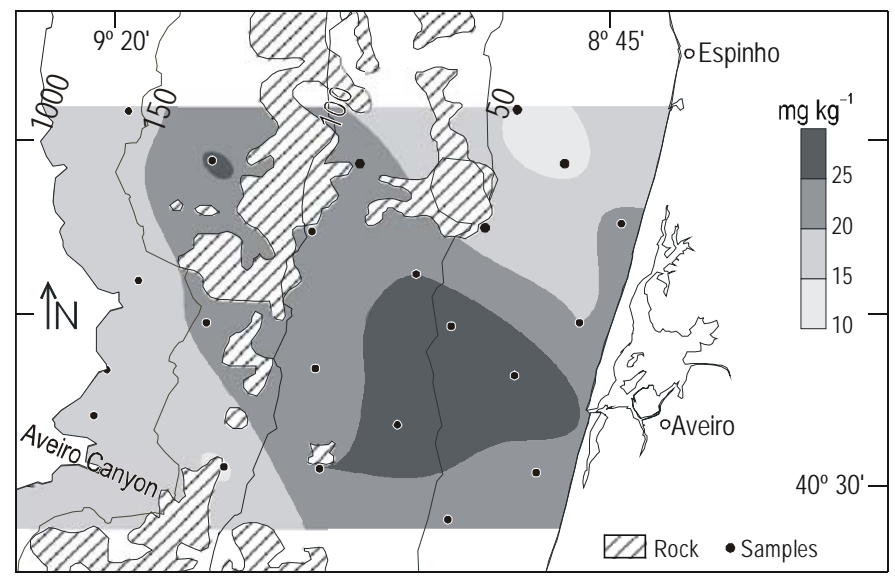

$\mathrm{Ca}$

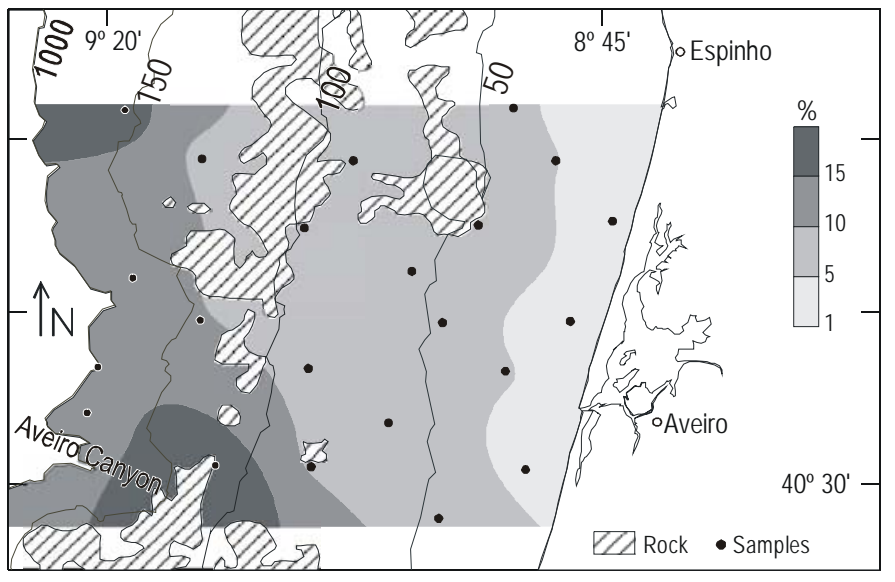

$\mathrm{Mg}$

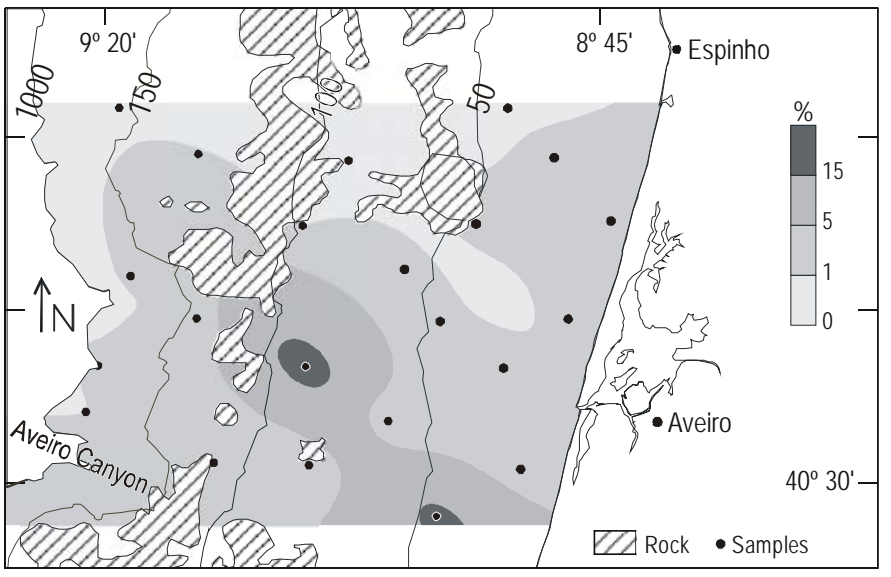

$\mathrm{Pb}$

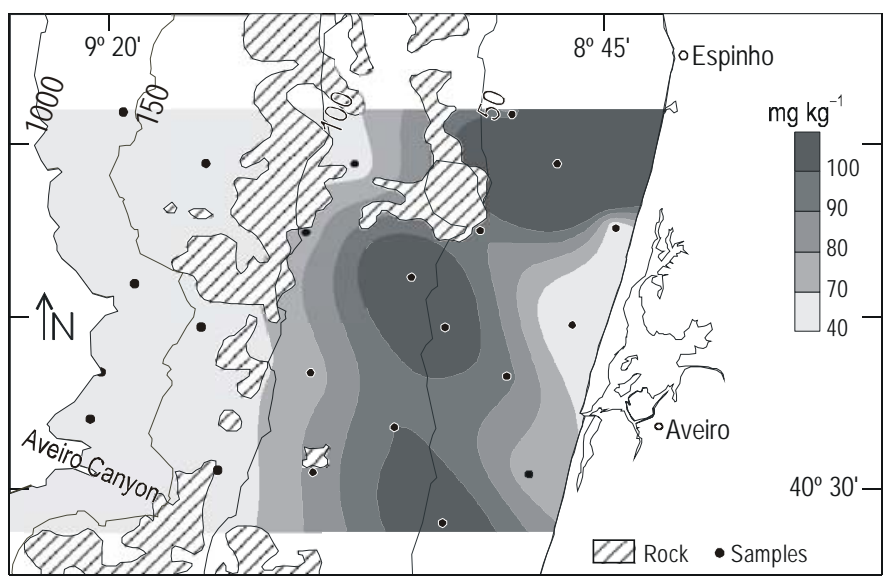

Figure 3. Distribution maps of the concentrations of $\mathrm{Al}, \mathrm{Ca}, \mathrm{Fe}, \mathrm{Mg}, \mathrm{Cu}$ and $\mathrm{Pb}$, in the fine fraction of shelf sediments between Espinho and Aveiro (Portugal). Figura 3. Mapas de distribución de las concentraciones de $\mathrm{Al}, \mathrm{Ca}, \mathrm{Fe}, \mathrm{Mg}, \mathrm{Cu}$ y $\mathrm{Pb}$, en la fracción fina de los sedimentos de la plataforma continental entre Espinho y Aveiro (Portugal).

The values of $\mathrm{Al}$, Fe and $\mathrm{Cu}$ are within currently accepted background levels (Salomons and Föstener, 1984), whereas Pb, $\mathrm{Zn}$, Cr and Ni show some anomalous values, higher than the currently accepted background levels, which may be related to anthropogenic contamination. All samples have Cd concentrations below the detection limit $\left(0.05 \mathrm{mg} \mathrm{kg}^{-1}\right)$. altos en la plataforma externa, donde los sedimentos están enriquecidos en partículas biogénicas carbonatadas, como restos de moluscos y foraminíferos.

La distribución de Fe mostró un enriquecimiento en la plataforma media y externa de la parte sur. Los contenidos de Mg presentaron una distribución homogénea, aunque dos muestras 
$\mathrm{Zn}$

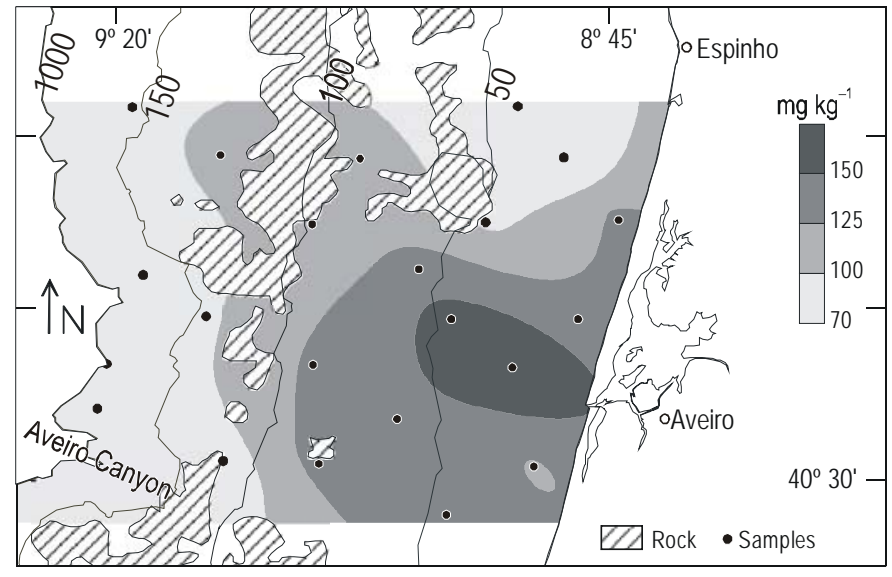

Co

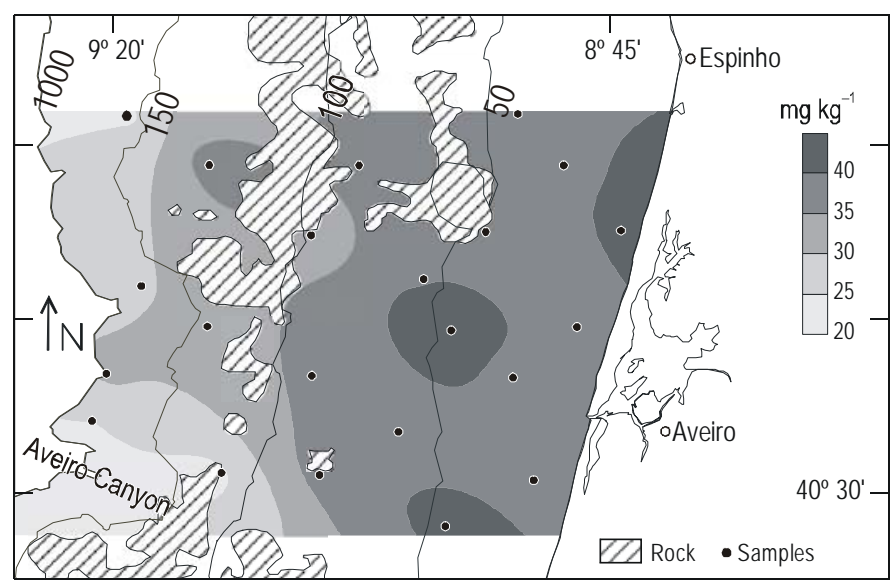

$\mathrm{Cr}$

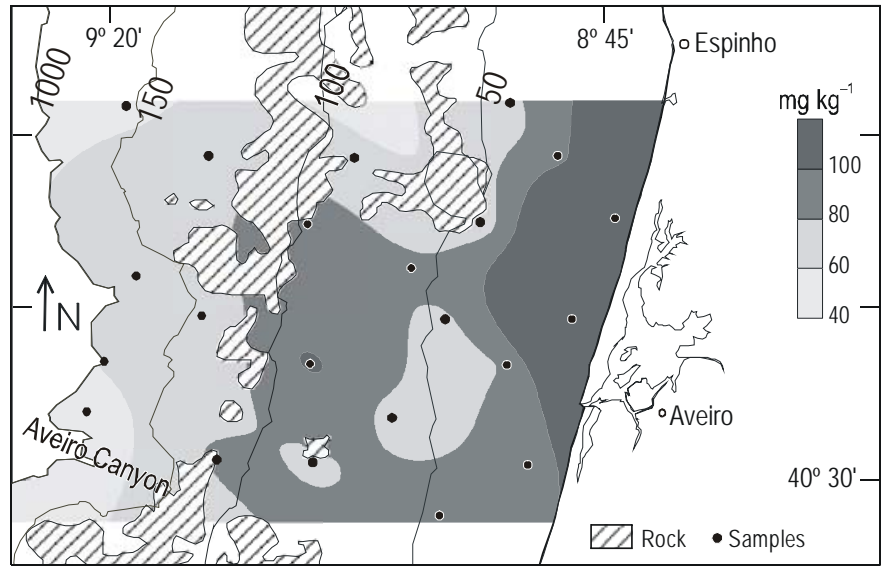

$\mathrm{Ni}$

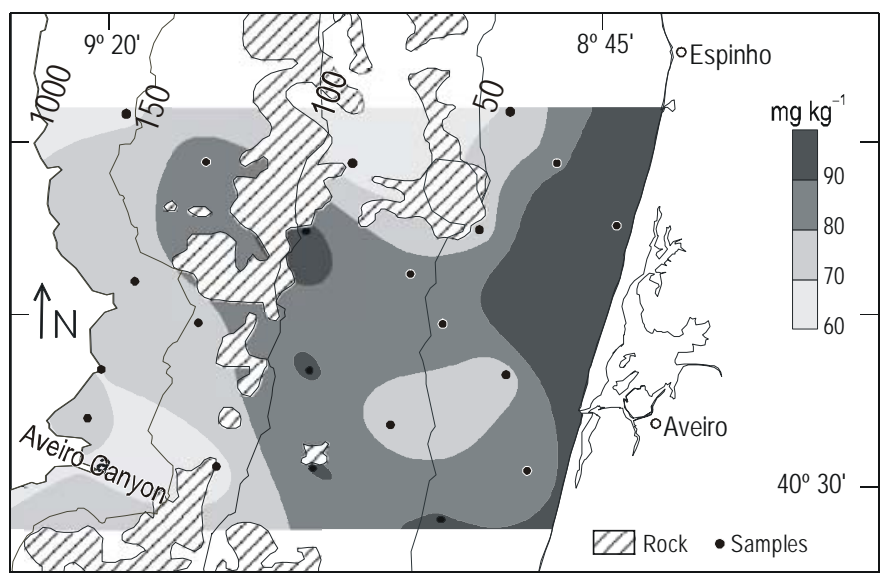

Figure 4. Distribution maps of the concentrations of $\mathrm{Zn}, \mathrm{Cr}, \mathrm{Co}$ and $\mathrm{Ni}$, in the fine fraction of shelf sediments between Espinho and Aveiro (Portugal).

Figura 4. Mapas de distribución de las concentraciones de $\mathrm{Zn}, \mathrm{Cr}$, Co y Ni en la fracción fina de los sedimentos de la plataforma continental entre Espinho y Aveiro (Portugal).

The highest concentrations of $\mathrm{Al}$ were found at depths above $100 \mathrm{~m}$. On the contrary, Ca contents increased westwards, with the highest values in the outer shelf, where the sediments are enriched in carbonate biogenic particles like debris of molluscs and foraminifers.

The distribution of Fe showed an enrichment in the midle and outer southern shelf zones. Mg contents presented a homogeneous distribution, although two samples located in the midshelf and in the outer southern shelf show concentration values much higher than the others.

The concentrations of $\mathrm{Cu}, \mathrm{Zn}, \mathrm{Cr}$, $\mathrm{Co}$ and $\mathrm{Ni}$ displayed a similar distribution pattern, decreasing seaward. The highest values of $\mathrm{Cu}$ and $\mathrm{Zn}$ were found in the inner and middle shelf sediments in front of the Ría de Aveiro mouth. However, the higher $\mathrm{Cr}$ and $\mathrm{Ni}$ concentrations occurred in the inner shelf region, extending mainly from the Ría de Aveiro mouth to the northern end of the study area.

The results obtained by Rocha et al. (2005) show that the surface and near-surface sediments of Aveiro Lagoon trap relatively large quantities of trace metals, such as $\mathrm{Cu}, \mathrm{Pb}, \mathrm{Co}, \mathrm{Ni}$, de la plataforma media y la plataforma externa de la parte sur muestran valores mucho mayores que las otras.

Las concentraciones de $\mathrm{Cu}, \mathrm{Zn}, \mathrm{Cr}$, Co y Ni presentaron un patrón de distribución similar, disminuyendo mar adentro. Los valores más altos de $\mathrm{Cu}$ y $\mathrm{Zn}$ se registraron en sedimentos de la plataforma interna y media, en frente de la boca de la Ría de Aveiro; sin embargo, los mayores valores de $\mathrm{Cr}$ y Ni se obtuvieron en la plataforma interna, desde la boca de la Ría de Aveiro hasta el extremo norte del área de estudio.

Los resultados obtenidos por Rocha et al. (2005) muestran que los sedimentos superficiales y los que se encuentran cerca de la superficie, en la Laguna de Aveiro, atrapan cantidades relativamente grandes de metales traza como $\mathrm{Cu}, \mathrm{Pb}, \mathrm{Co}, \mathrm{Ni}$, $\mathrm{Cd}, \mathrm{Zn}, \mathrm{Fe}, \mathrm{Mn}$ y $\mathrm{Cr}$, los cuales se consideran parcialmente adsorbidos en partículas de limo y arcilla, y también coprecipitados en oxihidróxidos de Fe y Mn precipitados en los niveles más superficiales de los sedimentos.

Los menores valores de estos metales, observados en la plataforma media, corresponden a las mayores concentraciones de otros metales (Al, $\mathrm{Cu}$ y Zn). El Pb presentó una concentración 
Cd, Zn, Fe, Mn and Cr, considered to be partially adsorbed, particularly on silty and clayey particles, and also may be coprecipitated on Fe and Mn oxyhydroxide forms precipitated in the topmost layers of sediments.

The lower values of these metals observed in the middle shelf correspond to the higher concentrations of other metals ( $\mathrm{Al}, \mathrm{Cu}$ and $\mathrm{Zn}$ ). Pb showed an unusually high concentration in the mid-shelf sediments.

Factor analysis was used to correlate elements and identify possible sediment sources. Table 2 lists the factor loadings and figure 5 presents the contoured maps of each sample's factor scores. The analysis showed an extraction of three factors, explaining $78.9 \%$ of the total variance:

- Factor 1 represents carbonated biogenic particles (Ca) in opposition to terrigenous non-carbonated particles (Al, Cu, $\mathrm{Zn}, \mathrm{Cr}, \mathrm{Co}$ and $\mathrm{Ni}$ ).

- Factor 2 explains Fe distribution, showing the positive scores in the northern outer shelf and in the southern at depths below $30 \mathrm{~m}$.

- Factor 3 represents $\mathrm{Pb}$ distribution with the higher values in the middle shelf.

The higher Al concentrations found at depths above $100 \mathrm{~m}$ are related to the input of sediments from the weathering of continental soils and rocks (composed mainly of aluminosilicates, such as micas, chlorites and feldspars).

The westward increase in $\mathrm{Ca}$ is in accordance with factor 2 mapping (fig. 5); this factor explains the distribution of biogenic particles, which have the highest values in the outer shelf near the head of Aveiro Canyon. The decrease in the supply of

Table 2. Factor loadings (unrotated) for the fine fraction of the sediments and variance explained by each factor.

Tabla 2. Cargas factoriales (sin rotar) para la fracción fina de los sedimentos y varianza explicada por cada factor.

\begin{tabular}{lccc}
\hline & Factor 1 & Factor 2 & Factor 3 \\
\hline $\mathrm{Al}$ & -0.93 & 0.08 & 0.13 \\
$\mathrm{Ca}$ & 0.81 & 0.42 & -0.19 \\
$\mathrm{Fe}$ & -0.49 & 0.64 & -0.24 \\
$\mathrm{Mg}$ & -0.31 & 0.22 & 0.03 \\
$\mathrm{Cu}$ & -0.71 & 0.57 & 0.14 \\
$\mathrm{~Pb}$ & -0.15 & -0.45 & 0.72 \\
$\mathrm{Zn}$ & -0.88 & 0.37 & 0.06 \\
$\mathrm{Cr}$ & -0.61 & -0.47 & -0.60 \\
$\mathrm{Co}$ & -0.85 & -0.23 & 0.34 \\
$\mathrm{Ni}$ & -0.68 & -0.45 & -0.52 \\
$\% \mathrm{Var}$ & 47.3 & 17.7 & 13.9 \\
\hline
\end{tabular}

extraordinariamente alta en los sedimentos de la plataforma media.

Se realizó un análisis factorial para correlacionar los elementos e identificar posibles fuentes del sedimento. En la tabla 2 se presentan las cargas factoriales y en la figura 5 se muestran los contornos de las puntuaciones factoriales de cada muestra. El análisis mostró una extracción de tres factores, explicando $78.9 \%$ de la varianza total:

- El factor 1 representa las partículas biogénicas carbonatadas (Ca) vs las partículas terrígenas no carbonatadas (Al, $\mathrm{Cu}, \mathrm{Zn}, \mathrm{Cr}, \mathrm{Co}$ y Ni).

- El factor 2 explica la distribución del Fe, mostrando puntuaciones positivas en la plataforma externa de la parte norte, y en la parte sur a profundidades menores que $30 \mathrm{~m}$.

- El factor 3 representa la distribución de Pb con valores mayores en la plataforma media.

Las concentraciones mayores de $\mathrm{Al}$ registradas a profundidades por encima de $100 \mathrm{~m}$ están relacionadas con los aportes de sedimentos por el intemperismo de suelo y rocas continentales (compuestas principalmente de aluminosilicatos, tales como micas, cloritas y feldespatos).

El aumento hacia el oeste del Ca concuerda con el trazado del factor 2 (fig. 5). Este factor explica la distribución de partículas biogénicas, que tienen valores mayores en la plataforma externa, cerca de la cabeza del cañón de Aveiro. La disminución en el aporte de partículas terrígenas asociada con un ambiente hidrodinámicamente más calmado y con alta productividad orgánica inducida por corrientes de surgencia sobre el cañón de Aveiro es probablemente responsable de los altos valores de Ca registrados en la plataforma externa de la parte sur.

La distribución de los contenidos de metales pesados $(\mathrm{Cu}$, Zn, Cr, Co y Ni) presentó una variación espacial, con concentraciones altas en la plataforma interna y media, y concentraciones bajas en la plataforma externa y la vertiente. También se observa este decremento general en otras áreas de la plataforma continental portuguesa, indicando que los metales pesados en los sedimentos de la plataforma han sido reducidos por procesos geoquímicos, durante el largo tiempo de residencia del material suspendido, por efectos de dilución y/o por mezclarse con partículas alóctonas, como partículas biogénicas carbonatadas (Araujo et al., 2002).

Los altos valores de $\mathrm{Cu}$ y $\mathrm{Zn}$ encontrados en los sedimentos de la plataforma interna y media en frente de la boca de la Ría de Aveiro, así como los patrones de distribución de las concentraciones de $\mathrm{Cr}$, Co y $\mathrm{Ni}$ nos permitieron considerar que las contribuciones provenientes de la Laguna de Aveiro (natural y antropogénica) y de sedimentos del norte (Río Douro y erosión costera) por la corriente costera o por corrientes advectivas, son las principales fuentes de metales pesados en la región. Al estudiar los sedimentos superficiales de la Laguna de Aveiro, 
terrigenous particles associated with a hydrodinamically calmer environment and also with high organic productivity induced by upwelling currents over Aveiro Canyon is probably responsible for the high $\mathrm{Ca}$ values displayed in the outer southern shelf.

The distribution of heavy metals $(\mathrm{Cu}, \mathrm{Zn}, \mathrm{Cr}, \mathrm{Co}$ and $\mathrm{Ni})$ displayed a spatial variation, with high concentrations in the inner-middle shelf and low concentrations in the outer and upper slope sediments. This general decrease is also observed in other areas of the Portuguese continental shelf and indicates that heavy metals of the shelf sediments have been depleted by geochemical processes, during the long residence time of suspended material, by dilution effects and/or by mixing with allochthonous particles such as biogenic carbonate particles (Araujo et al., 2002).

The high values of $\mathrm{Cu}$ and $\mathrm{Zn}$ found in the inner and middle shelf sediments in front of the Ría de Aveiro mouth, as well as the distribution patterns of $\mathrm{Cr}$, $\mathrm{Co}$ and $\mathrm{Ni}$ concentrations allowed us to consider that inputs from Aveiro Lagoon (natural and anthropogenic) and from northern sediments (Douro River and coastal erosion) by littoral drift or by advective currents are the main sources of heavy metals in this region. Studying
Rocha et al. (2005) encontraron una clara asociación entre las variables de Ni y Cr. La particular distribución cartográfica de las puntuaciones factoriales sugiere un control litológico/mineralógico (relacionado con lodos ricos en vermiculita y esmectita) o cierto grado de influencia de los diferentes complejos químicos alrededor de la laguna (Ovar, Estarreja e Ílhavo). Además, señala la influencia de las actividades navales (dársena y astillero) asociadas con el puerto de Aveiro (localizado cerca de la boca de la laguna).

El factor 2 está asociado con la distribución de Fe. En vista de que el Fe es un elemento comúnmente presente en la matriz cristaloquímica de minerales arcillosos, este factor puede estar relacionado con cambios en las asociaciones de minerales arcillosos. Por tanto, el enriquecimiento de $\mathrm{Fe}$ en la plataforma media y externa de la parte sur puede ser atribuido a minerales arcillosos como esmectita y clorita. En realidad, la esmectita presenta valores mayores en la plataforma externa de la parte sur, la cual parece ser un área de baja energía favorable para la depositación de este mineral de grano muy fino (Abrantes et al., 2001).

Como ya se mencionó, el $\mathrm{Pb}$ mostró una concentración excepcionalmente alta en los sedimentos de la plataforma
Factor 1

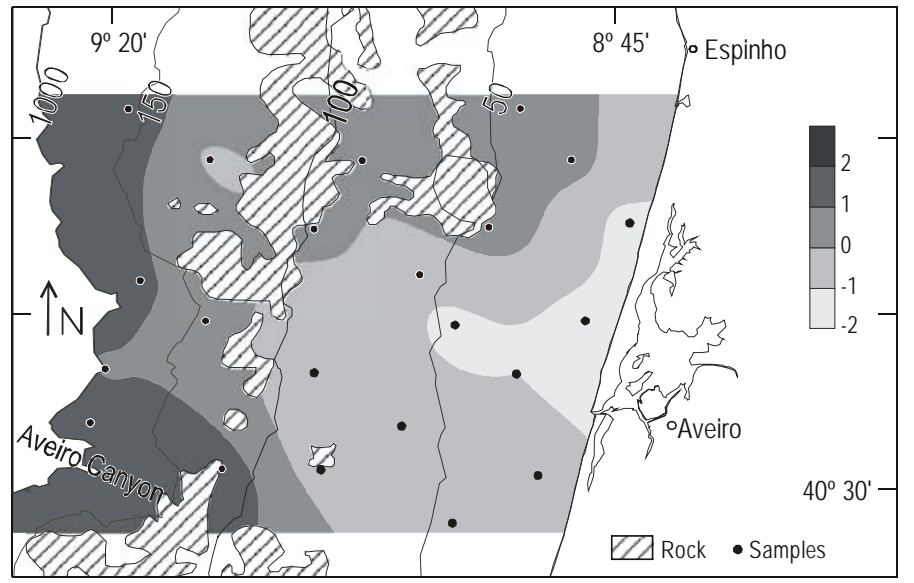

Factor 2

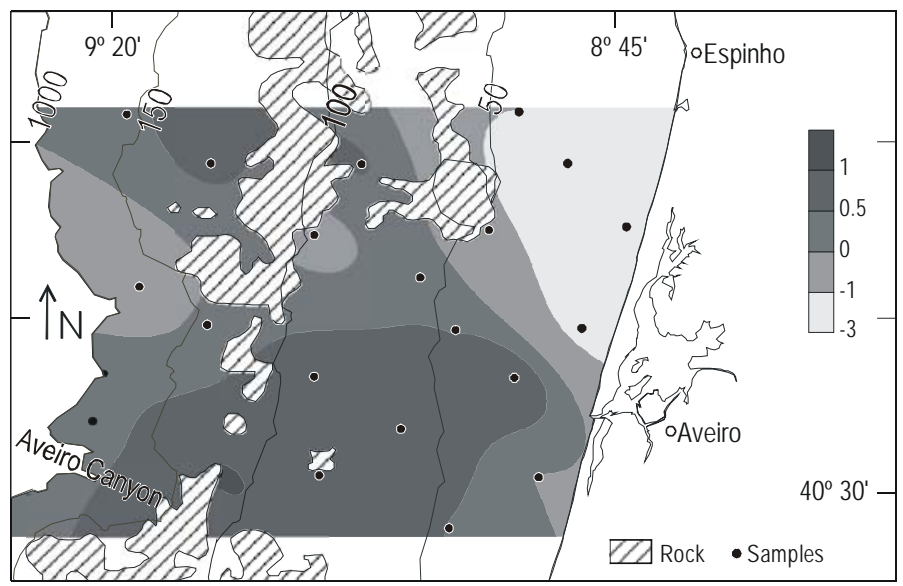

Factor 3

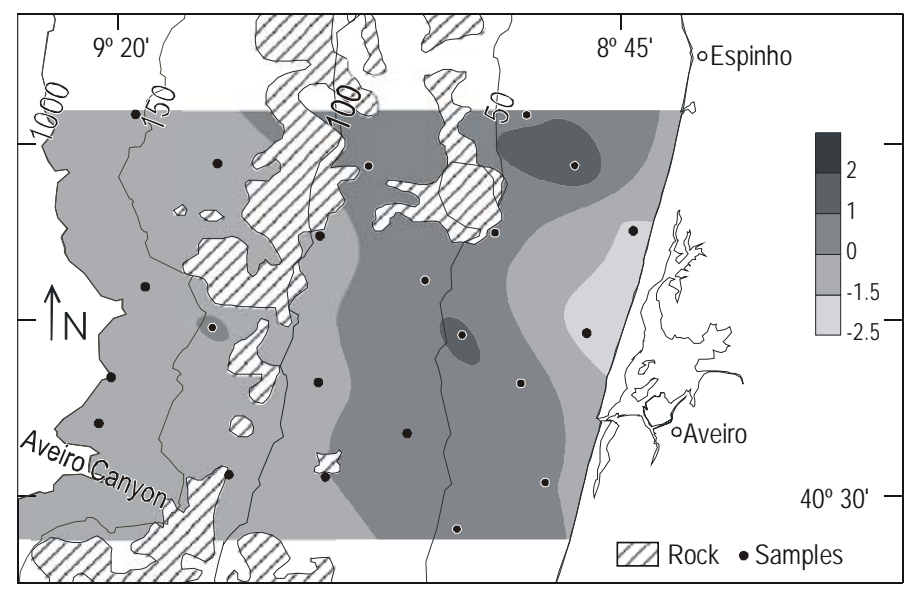

Figure 5. Factor scores for the samples analyzed $(n=22)$.

Figura 5. Puntuaciones factoriales para las muestras analizadas $(n=22)$. 
the surface sediments of Aveiro Lagoon, Rocha et al. (2005) found a clear association between $\mathrm{Ni}$ and $\mathrm{Cr}$ variables, the peculiar cartographic distribution of the factor scores suggesting either a lithological/mineralogical control (related to vermiculite and smectite rich muds) or some influence of different chemical parks surrounding the lagoon (Ovar, Estarreja and Ílhavo), and pointing out the influence of the naval activities (port and shipyards) linked with Aveiro harbour (located close to the lagoon mouth).

Factor 2 is associated with Fe distribution. As Fe is an element commonly present in the crystallochemical matrix of clay minerals, this factor can be related to changes in clay mineral associations. Therefore, Fe enrichment in the middle and outer southern shelf zones can be attributed to clay minerals such as smectite and chlorite. Actually, smectite has higher values in the southern outer shelf, which seems to be a low-energy area favourable for the deposition of this very fine-grained mineral (Abrantes et al., 2001).

As we have already stated, $\mathrm{Pb}$ showed an unusually high concentration in the mid-shelf sediments, but the distance from the coast and the localization of these highest $\mathrm{Pb}$ levels does not suggest anthropogenic enrichment from a point source. So, these values must be further investigated.

In summary, particulate metals from natural and anthropogenic sources accumulate together and tend to be concentrated in the fine-grained particles from the inner and middle shelf. The $\mathrm{Al}$ and heavy metal concentrations displayed a similar distribution pattern, decreasing seaward. Exceptions to this general pattern are $\mathrm{Ca}, \mathrm{Mg}$ and $\mathrm{Pb}$ distributions. The $\mathrm{Ca}$ contents are related to carbonated biogenic particles that are very abundant in the outer shelf. The major factors controlling the spatial variations of the elements analyzed in the study area are terrigenous supply from Ría de Aveiro, coastal erosion and Douro River; grain size (clay) sorting; and anthropogenic influences from Aveiro Lagoon.

\section{Acknowledgements}

The authors sincerely thank the Hydrographic Institute for providing the sampling to carry out the chemical analysis.

\section{References}

Abrantes, M.I. (1994). A cobertura sedimentar da plataforma e vertente continental entre Espinho e Aveiro. M.Sc. thesis, Aveiro University, 178 pp.

Abrantes, I. and Magalhães, F. (2000). Dinâmica sedimentar actual da plataforma e vertente continental entre Espinho e Aveiro: Modelo conceptual e Balanço. $3^{\circ}$ Simpósio sobre a Margem Continental Ibérica Atlântica, Faro, pp. 221-222.

Abrantes, I., Magalhães, F. and Dias, J.M.A. (1994). Characterisation of the surface sediments of the continental shelf and upper slope between Espinho and Aveiro. Gaia, 8: 97-104.

Abrantes, I., Rocha, F. and Dias, J.M.A. (2001). Mineralogical characterization of the clay fraction of the sediments of the continental shelf and upper slope between Espinho and Aveiro (Portugal). Nuevas Tendencias en el Estudio de las Arcillas, Sociedad Española de Arcillas, pp. 76-79. media, pero la distancia de la costa y la localización de estos niveles altos de $\mathrm{Pb}$ no indica enriquecimiento antropogénico de una fuente puntual. Por tanto, estos valores necesitan estudiarse más a fondo.

En conclusión, los metales particulados de fuentes naturales y antropogénicas se acumulan y tienden a concentrarse en las partículas de grano fino de la plataforma interna y media. Las concentraciones de $\mathrm{Al}$ y metales pesados presentaron un patrón de distribución similar, disminuyendo hacia la vertiente. Las excepciones a este patrón general son las distribuciones de $\mathrm{Ca}, \mathrm{Mg}$ y $\mathrm{Pb}$. Los contenidos de Ca están relacionados con partículas biogénicas carbonatadas que son muy abundantes en la plataforma externa. Los principales factores que controlan las variaciones espaciales de los elementos químicos analizados en el área de estudio son la contribución terrígena de la Ría de Aveiro, la erosión costera y el Río Douro; el tamaño de grano (arcilla); y la influencia antropogénica de la Laguna de Aveiro.

\section{Agradecimientos}

Los autores agradecen al Instituto Hidrográfico los muestreos realizados para poder llevar a cabo los análisis químicos.

Traducido al español por Christine Harris.

Abrantes, I., Rocha, F. and Dias, J.M.A. (2002). Clay minerals distribution in shelf surface sediments between Espinho and Cabo Mondego (Portugal). La Investigación de Arcillas en Geología, Agricultura, Médio Ambiente y Ciência de Materiales. Sociedad Española de Arcillas, pp. 55-58.

Araujo, M.F., Jouanneau, J.M., Valério, P., Barbosa, T., Gouveia, A., Weber, O., Oliveira, A., Rodrigues, A. and Dias, J.M.A. (2002). Geochemical tracers of northern Portuguese estuarine sediments on the shelf. Prog. Oceanogr., 52: 277-297.

Cascalho, J.P.V. (2000). Mineralogia dos sedimentos arenosos da margem continental setentrional portuguesa. Ph.D. thesis, Lisbon University, 400 pp.

Cascalho, J. and Magalhães, F. (2000). Sediment dispersal in the north Portuguese continental shelf. $3^{\circ}$ Simpósio sobre a Margem Continental Ibérica Atlântica, Faro, pp. 255-256.

Davis, J.C. (1986). Statistics and Data Analysis in Geology. Wiley, New York, 646 pp.

Dias, J.M.A. (1987). Dinâmica sedimentar e evolução recente da plataforma continental portuguesa setentrional. Ph.D. thesis, Lisbon University, 384 pp.

Dias, J.M.A. and Nittrouer, C.A. (1984). Continental shelf sediments in northern Portugal. Cont. Shelf Res., 3: 147-165.

Dias, J.M., Lopes, J.F. and Dekeyser, I. (1999). Hydrological characterisation of Ria de Aveiro, Portugal, in early summer. Oceanol. Acta, 22(5): 473-485.

Drago, T., Oliveira, A., Magalhães, F. Cascalho, J., Jouanneau, J.M. and Vitorino, J. (1998). Some evidence of the northward fine sediment transport in the northern Portuguese continental shelf. Oceanol. Acta, 21: 223-231.

Drago, T., Naughton, F., Moreno, J., Rocha, F., Cachão, M., Sanchez Gõni, M.F., Oliveira, A., Cascalho, J., Fatela, F., Freitas, C. and Andrade, C. (2002). Geological record of environmental changes in the Douro Estuary (NW Portugal): Since the Late Glacial. Proc. Littoral' 2002: 6th EUROCOAST International Conference, III, pp. 341-346. 
Fiúza, A.F.G. (1983). Upwelling patterns off Portugal. In: Coastal upwelling: Its sediment record. Plenum Press, New York, pp. 8598.

Fiúza, A.F.G., Macedo, M.E. and Guerreiro, M.R. (1982). Climatological space and time variation of the Portuguese coastal upwelling. Oceanol. Acta, 5: 31-40.

Garrett, R.G. (1973). The determination of sampling and analytical errors in exploration geochemistry. Econ. Geol.,68: 282-283.

Imbrie, J. and Van Andel, T.H. (1964). Vector analysis of heavymineral data. Bull. Geol. Soc. Am., 75: 1131-1156.

Jöreskob, K.G., Klovan, J.E. and Reyment, R.A. (1976). Geological Factor Analysis. Elsevier, Amsterdam, 178 pp.

Lecomte, P. and Sondag, F. (1980). Regional geochemical reconnaissance in the Belgian Ardenness, secondary dispersion patterns in stream sediments. Miner. Deposita, 15(1): 47-60.

Loring, D.H. (1991). Normalization of heavy-metal data from estuarine and coastal sediments. ICES. J. Mar. Sci., 48: 101-105.

Machado, A., Rocha, F. and Gomes, C. (1999a). Statistical analysis of mineralogical parameters used as lithostratigraphic markers. Application to Quaternary sediments of the littoral between Espinho and Furadouro (Portugal). Bol. Inst. Esp. Oceanogr., 15(1-4): 303-312.

Machado, A., Silva, A.P., Rocha, F. and Gomes, C. (1999b). Heavy metals versus clay minerals in the Quaternary sediments of the Cortegaça beach formation (Ovar, Portugal). Estudos do Quaternário. Rev. Ass. Port. Est. Quatern., 2: 19-25.

Machado, A., Rocha, F., Dias, A. and Gomes, C. (2000). Distribution patterns of clay minerals in the surficial sediments of the continental shelf off Guadiana Estuary (Algarve, Portugal): A preliminary study. Proc. 1st Latin American Clay Conference, Ass. Port. Argilas, Vol. 2, pp. 64-68.

Machado, A., Rocha, F., Dias, A. and Gomes, C. (2001a). Application of statistical analysis to clay minerals data corresponding to recent sediments from the continental shelf off Guadiana Estuary. Nuevas Tendencias en el Estudio de las Arcillas (Actas da XVI Reun. Cient. Soc. Esp. Arcillas), pp. 92-94.

Machado, A., Rocha, F., Dias, J.A. and Gomes, C. (2001b). Mineralogical characterisation of fine sediments of the continental shelf off Guadiana estuary. Actas do V Congresso do Quaternário de Países de Línguas Ibéricas. V Reunião do Quaternário Ibérico, Lisboa, pp. 214-217.

Machado, A., Rocha, F., Gomes, C. and Dias, J.A. (2002). Clay minerals identified in the suspended particulate matter of the Guadiana Estuary, during a tidal cycle. La Investigación de Arcillas en Geología, Agricultura, Médio Ambiente y Ciência de Materiales (Actas da XVII Reun. Cient. Soc. Esp. Arcillas), pp. 177-180.

Magalhães, F. (1993). A cobertura sedimentar da plataforma e da vertiente continental superior a norte de Espinho. M.Sc. thesis, Lisboa, Lisbon University, 191 pp.

Magalhães, F. (1999). Os sedimentos da plataforma continental portuguesa: Contrastes espaciais, perspectiva temporal, potencialidades económicas. Ph.D. thesis, Lisbon University, $289 \mathrm{pp}$.

Martins, V., Gomes, C., Dias, J., Rocha, F., Sequeira, C., Gomes, V., Moreno, J. and Mendes, I. (2001a). Palaeoceanographic reconstruction of the Galician continental slope during the Quaternary based on sediments textural features and on foraminifera density and characteristics. Actas do V Congresso do Quaternário de Países de Línguas Ibéricas. V Reunião do Quaternário Ibérico, Lisboa, pp. 218-222.

Martins, V., Rocha, F., Sequeira, C., Jouanneau, J., Weber, O., Gomes, C., Dias, J.A. and Gomes, V. (2001b). Clay minerals assemblages, sediments texture and foraminifera biostratigraphy used for palaeoceanographic reconstruction of the Galicia continental shelf during the Holocene. Nuevas Tendencias en el Estudio de las Arcillas (Actas da XVI Reun. Cient. Soc. Esp. Arcillas), pp. 98101.

Martins, V., Rocha, F., Gomes, V. and Gomes, C. (2002). Clay minerals and foraminifera assemblages used to identify climatic and sea level changes registered in the Holocenic sedimentary record of Ria de Vigo. La Investigación de Arcillas en Geología, Agricultura, Médio Ambiente y Ciência de Materiales (Actas da XVII Reun. Cient. Soc. Esp. Arcillas), pp. 101-105.

Mezzadri, G. and Saccani, E. (1989). Heavy mineral distribution in Late Quaternary sediments of the southern Aegean sea: Implications for provenance and sediment dispersal in sedimentary basins at active margins. J. Sediment. Petrol., 59: 412-422.

Moreira, M.H., Queiroga, H., Machado, M.M., and Cunha, M.R. (1993). Environmental gradients in a southern estuarine system: Ria de Aveiro, Portugal. Implication for soft bottom macrofauna colonization. Neth. J. Aquat. Ecol., 27(2-4): 465-482.

Oliveira, A., Rocha, F., Alveirinho Dias, J., Gomes, C. and Rodrigues, A. (1998). Bottom sediments of the northern Portuguese shelf: Patterns of clay minerals distribution. Proc. 2nd Mediterranean Clay Meeting, Univ. Aveiro, Vol. 2, pp. 173-179.

Oliveira, A., Vidinha, J., Rocha, F., Rodrigues, A., Jouanneau, J., Dias, J.A. and Gomes, C. (2000). Discriminant analysis applied to the mineralogy of sediments (fine and clay fractions) from the NW Iberian margin. Proc. 1st Latin American Clay Conference, Ass. Port. Argilas, Vol. 2, pp. 7-13.

Oliveira, A., Rocha, F., Rodrigues, A. and Dias, J.A. (2001). Mineralogy of the fine fraction of the sediments as dynamic sedimentary tracers: NW Iberian Margin. Thalassas, 17: 35-44.

Oliveira, A., Rocha, F., Rodrigues, A., Jouanneau, J., Dias, J.A., Weber, O. and Gomes, C. (2002). Clay minerals of the sedimentary cover from the northwestern Iberian shelf. Prog. Oceanogr., 52(2-4): 233-247.

Reyment, R. and Jöreskob, K.G. (1993). Applied Factor Analysis in the Natural Sciences. Cambridge Univ. Press, Cambridge, U.K., 369 pp.

Rocha, F., Silva, E., Bernardes, C., Vidinha, J. and Patinha, C. (2005). Chemical and mineralogical characterisation of the sediments from the Mira, Ílhavo and Ovar channels of the Aveiro Lagoon, Portugal. Cienc. Mar., 31(1B): 243-251.

Salomons, W. and Föstener, U. (1984). Metals in the Hydrocycle. Springer Verlag, Berlin.

Vicente, C.M. (1985). Caracterização hidráulica e aluvionar da Ria de Aveiro: Utilização de modelos hidráulicos no estudo da problemas da Ria. Jornadas da Ria de Aveiro, Edição da Câmara Municipal de Aveiro, Portugal, Vol. III, pp. 41-45.

Vidinha, J., Rocha, F., Andrade, C. and Gomes, C. (1998). Mineralogical characterization of the fine fraction of the beach and dune sediments situated between Espinho and Torreira (Portugal): A geostatistical approach. Cuaternario y Geomorfologia, 12(3/4): 49-56.

Vidinha, J., Oliveira, A., Rocha, F. and Gomes, C. (2000). Clay minerals distribution in the littoral and continental platform in relation to circulation/paleocirculation. Proc. International Symposium on Clays in Relation to Environment and Industry. ISCREI 2000, Annamalai University (India), pp. 45-58.

Vidinha, J., Rocha, F. and Andrade, C. (2002). Source areas of recent sediments of the Portuguese western Atlantic coast (Espinho Cape Mondego). Mineralogical Evidences. Proc. Littoral' 2002: 6th EUROCOAST International Conference, II, pp. 477-483.

Vitorino, J., Oliveira, A., Jouanneau, J.M. and Drago, T. (2000). Winter dynamics and transport of fine sediments on the northern 
Portuguese shelf. $3^{\circ}$ Simpósio sobre a Margem Continental Ibérica Atlântica, Faro, pp. 279-280.

Vitorino, J., Oliveira, A., Jouanneau, J.M. and Drago, T. (2002). Winter dynamics on the Portuguese shelf. Part 1: Physical processes. Prog. Oceanogr., 52, pp. 129-153.
Wooster, W.S., Bakun, A. and McLain, D.R. (1976). The seasonal upwelling cycle along the eastern boundary of the North Atlantic. J. Mar. Res., 34: 131-141. 